\title{
Opportunities and challenges for transdisciplinary research in flood risk manage- ment: some critical reflections and lessons learnt for research on sustainability
}

\author{
Thomas Thaler, Christoph Clar, Lena Junger \& Ralf Nordbeck \\ Keywords: disaster risk management, sustainable management, transdisciplinarity, co-design
}

\begin{abstract}
Mountain hazards such as floods, torrents or landslides pose a serious threat to human lives and repeatedly cause considerable damage in the Alpine region. Shrinking populations also provide a socio-political challenge for regional and local authorities. Within the ÖAW-ESS funded DemoHazAlps project, the aim is to develop a better understanding of demographic change as a key driver in transforming risk patterns. A transdisciplinary research strategy was chosen to address these challenges in the Gailtal, in the Austrian province of Carinthia. This paper describes the use of transdisciplinary research above all to integrate the knowledge of those who are affected by, and those who can affect the planning of, risk management. Transdisciplinary research has a high potential to contribute to overcoming conflicts in flood risk management triggered by, and linked to, demographic change. However, in practice there are many limitations and barriers to consider, such as the negative connotations of risk management or a pandemic. This paper provides some critical reflection on transdisciplinary research to address limitations and barriers; the lessons learnt could be applied in similar situations, for example within UNESCO biosphere reserves.
\end{abstract}

\section{Introduction}

New developments in flood risk management expand the range of perspectives and tools for both practitioners and scholars (Krueger et al. 2016; Löschner et al. 2016; Thompson et al. 2017; Clar et al. 2021). Pressure on hazard risk management has increased as a result of the impacts of climate change and changes in land use, which have necessitated new approaches, from assessing societal behaviour to increasing attention on non-structural mitigation measures (Seebauer et al. 2019; Clar et al. 2021). One of the new challenges resulting from these changes in flood risk management is the tension between the sustainable management of UNESCO biosphere reserves (BRs) and the protection of municipalities (Warner \& Damm 2019). Developments in interdisciplinary research offer important inputs for our understanding of these challenges. However, the obvious links between social and natural developments and the demand for new long-term solutions also call for stronger connections between practice and science. DemoHazAlps (Demographic change and hydrological hazards: flood risk management in Alpine areas facing population decline and demographic ageing) is a research project funded under the ÖAW-Earth System Science (ESS) programme. In this project, an interdisciplinary research team analysed the links between, and mutual influences of, demographic change (ageing, outmigration, changing household structures, and pluralization of society) and the management of flood risks in the Gailtal, the (rural) valley of the Gail, in the Austrian province of Carinthia (see Infobox and Figure 1). In the course of our research, we encountered a series of challenges, above all a surprising lack of knowledge at the intersection of flood hazards, demographic change and transdisciplinary research (Clar 2019). In addition, the coronavirus pandemic has influenced the activities of municipalities, and the research activities at universities and independent research institutes alike. Apple (2021) has shown that research activities within relatively remote areas, such as GLORIA sites, could in principle be conducted without any modifications. However, restrictions due to the pandemic have hindered the planning of transdisciplinary research activities, which are crucial, methodologically, within this field (Kratzer 2018a, b; von Lindern et al. 2019; Ammering et al. 2020). Based on these experiences, we try to identify other areas (notably in the management of BRs) in which our approach could be relevant. The paper describes the attempt to apply a transdisciplinary perspective within this complex framework, above all to integrate the knowledge of those affected by risk management planning and of those who can influence it directly.

\section{Transdisciplinary research in the manage- ment of the environment}

It is here that the concept of transdisciplinarity comes into play. Transdisciplinarity can be defined as the joint generation of knowledge by different academic disciplines, practitioners and / or non-scientific actors, with the goal of solving societal or real-world problems (Jahn et al. 2012; Klein et al. 2001). Among other things, it implies the integration of stakeholders not simply as spectators and commentators but as participants and co-producers of strategies, measures, policy developments, etc. (Seebauer et al. 2019; Clar forthcoming). Transdisciplinary research became particularly popular in the late 1990s and at the beginning of the 2000s. Many research teams developed 


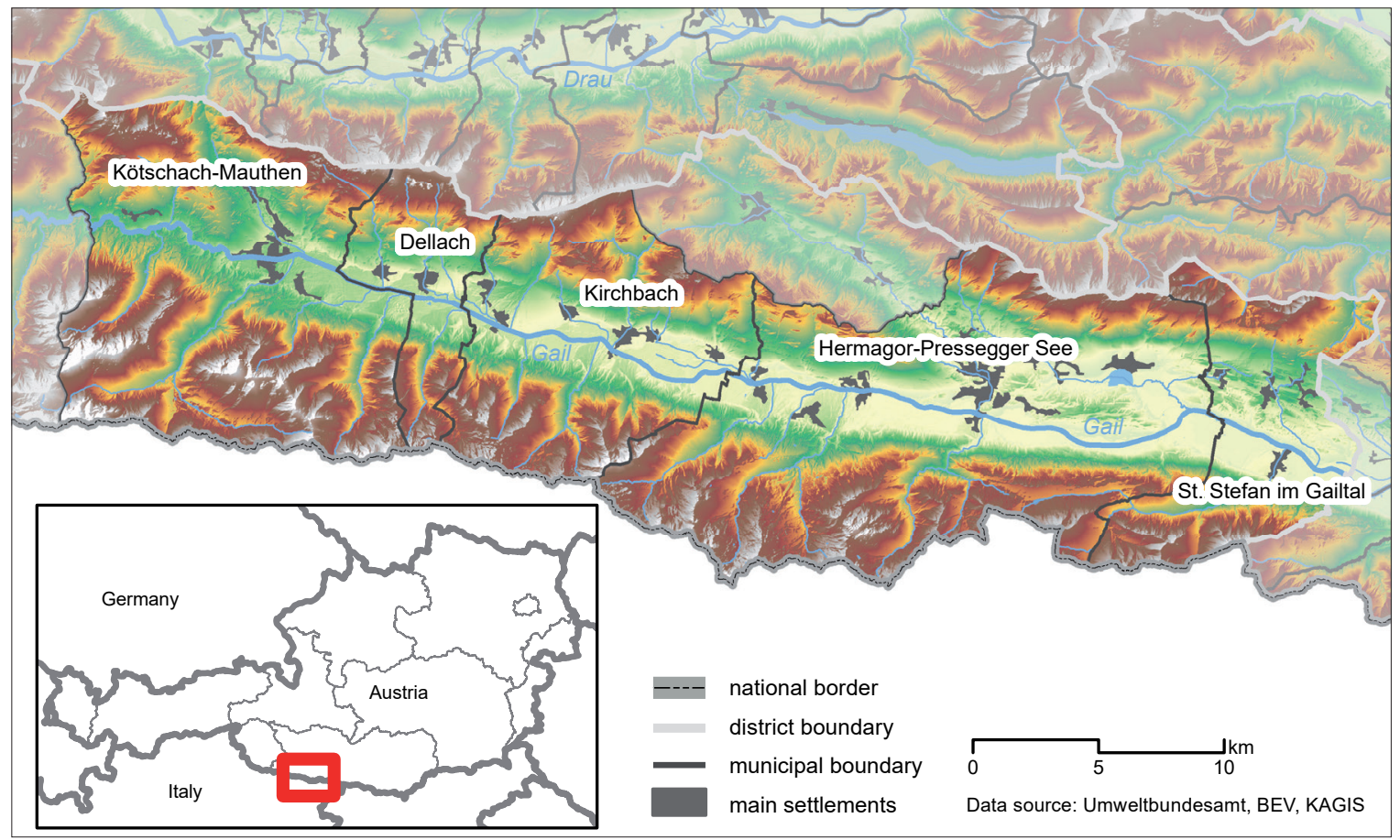

Figure 1 - Location of the Gailtal.

transdisciplinary approaches that were supposed to improve the understanding of sustainable management concepts, and contribute to their development, including through the reduction of conflicts in politically sensitive situations like the creation of large protected areas (Meesen et al. 2015). These developments were encouraged significantly by research and innovation initiatives at international and national levels, such as the Horizon 2020 programme of the European Union, the Sustainable Development Goals (SDGs), UNESCO's Man and the Biosphere (MAB) programme, or the Earth System Sciences Programme, led by the Austrian Academy of Sciences (ÖAW-ESS) for the Austrian Federal Ministry of Education, Science and Research. These programmes foresee the close integration of multiple stakeholders in research projects. Transdisciplinary research often comes into play when there are several stakeholders affected by a similar situation, who at the same time differ from each other in their views and values (Daniels \& Walker 2001). Although there is no universally accepted framework for integrating transdisciplinary knowledge, terms like participatory research, public participation and transdisciplinary describe interdisciplinary research that aims to integrate academic and non-academic data in the production of knowledge (Vilsmaier 2010; Hoffmann et al. 2017). This approach actively includes stakeholders from various sectors (Angelstam et al. 2013). Although the different perspectives on research problems promise new insights, they also create new challenges, such as a significant increase in the number of actors to be integrated in the study design, or far greater complexity in reaching a consensus regarding the general principles of a particular research project (Stauffacher et al. 2008; Vilsmaier 2010). Different stakeholders use different approaches to problem solving and use different communication channels. Indeed, it is crucial to understand differences regarding the interests of diverse stakeholders, as well as their connections to different levels of government (regional, national, international) (Angelstam et al. 2013). Key challenges are to make different stakeholders' knowledge relevant to specific decisions (Pielke et al. 2010), and to integrate the range of stakeholders into the process of developing innovative and transformative solutions in policy planning (Angelstam et al. 2013). For example, in water resource management, transdisciplinary research allows better understanding of human-water relations, and thereby the creation of appropriate intervention strategies (Krueger et al. 2016). However, experience and so-called success or positive-outcome studies demonstrate that the implementation of transdisciplinary approaches is more likely to be successful

Infobox - The Gailtal in Carinthia (Austria)

The district of Hermagor is located in southwestern Carinthia, bordering Italy to the south and the province of Tyrol to the west. The district is sparsely populated and very peripherally located. The population density in the district of Hermagor is 23 per $\mathrm{km}^{2}$. The district was highly affected by various extreme flood events, as in 1965/66 and 2018 . In addition, there are poor supra-regional transport links. There are a large number of protected areas across the valley, some of them in the floodplains. The implementation of protected areas created land-use conflicts very similar to those caused by the implementation of flood risk management strategies in the district. 
when the municipality concerned gains from associated interventions. More conflict-laden thematic areas, like the creation of protected areas, sustainable management of mineral resources or water quality, often harness transdisciplinary research projects (Scholz \& Steiner 2015; Krueger et al. 2016). The main question is how to use and implement transdisciplinary research processes in cases that are associated with negative developments (such as diminishing populations in rural areas), or where relatively few people stand to lose much (such as flood risk management in areas that are becoming depopulated). Flood risk management and shrinking of municipalities are generally difficult issues for policy makers, stakeholders and citizens within the regions concerned. In particular, population decline is often seen as having strongly negative consequences for municipalities, such as less income from local taxes or the closure of social infrastructure (e. g. social housing, public libraries, schools or public transport) (Clar et al. 2021). As we experienced in DemoHazAlps, the situation is even worse when both challenges (depopulation and managing flood risks) are addressed within one single project.

\section{Transdisciplinary research in DemoHazAlps during the coronavirus pandemic}

Due to the structure of current research funding, it was impossible to develop a truly transdisciplinary project, which would have included the joint development of the research project from the ground up (including integrating stakeholders in drawing up the project proposal), the identification of vulnerabilities, the refinement of research questions, and the design of the research approach, etc. (Scherhaufer \& Grüneis 2014). However, integrating stakeholders at all relevant governmental levels (federal, provincial, regional, local) early in the research process enabled us to focus in on and clarify the actual problem(s) and phenomena we were dealing with, the research questions, and the possible outcomes of our research (i. e. adaptation strategies at local level), in addition to scientific publications.

Our first step entailed consultations with national and regional decision-makers to discuss potential participants at regional level. Within this step, we co-developed a framework that would allow us to integrate the knowledge of practitioners (e.g. regional experts in flood risk management, land use planning, emergency management) within our research process. We also defined common research questions and problems, and identified major challenges - for example, the development of a common understanding of the problem and a common language, the integration of stakeholders' knowledge into scientific outputs (which requires additional effort), and above all communication as equals. Later, we recruited stakeholders at local level. It became apparent that we needed to address two main challenges: first of all, on the part of the public administration there had been strong scepti- cism towards negative issues such as floods, as well as prejudices and stereotypes; second, there were also misunderstandings between practitioners and scholars within our project, and misconceptions.

The second step foresaw interactions with local policy makers and stakeholders. Our procedure at the local level was similar to the one we conducted at the regional level, where most policy makers and stakeholders were keen to participate and offered significant commitment. However, at the local level we encountered surprisingly strong reservations, with serious consequences for our case study. After initial interest in DemoHazAlps, the largest municipality within the selected region, Hermagor-Pressegger See, declined to collaborate - because, according to the Mayor, both topics were "too negative". Similar concerns and objections have been observed in the creation or enlargement of protected areas, such as the former BR Gurgler Kamm (Austria), or rejection of the Parc Adula national park (Switzerland) (Michel 2019). Protected areas usually face socio-demographic changes similar to those seen in the DemoHazAlps case study (Rumpolt et al. 2016), and local decision-makers and citizens are confronted by similar concerns to those of the Mayor of Hermagor Pressegger - a fall in revenue from taxes, and closure of social infrastructure (housing, libraries and so on).

As suggested in informal talks, the key concern was the possibility of negative consequences following our research. For instance, the municipality might face exclusion from flood risk management schemes because of socio-demographic developments, such as population decline or ageing. A smaller number of households in at-risk zones would influence the decisionmaking process by lowering the cost-benefit ratio, which is central within the decision-making process regarding whether to protect a municipality. While this is of course a serious concern, it seems unlikely in this instance to have had any impact on current policies. Moreover, the maintenance costs of flood protection schemes are a serious issue. Fewer citizens would mean reduced income from taxes for the local authority, which might create financial difficulties when it comes to ensuring that the municipality can meet the costs. The loss of collaboration with the large municipality, Hermagor-Pressegger See, had a negative impact on our research activities within the region.

A second challenge for our collaboration with stakeholders has obviously been the coronavirus pandemic, which influenced our activities within the study sites to a very high degree. During the first lockdown, due to team members' childcare obligations, meetings had to be scheduled for late evening or very early morning. Most stakeholders had other far more immediate concerns than discussing the interrelations of flood risk management and socio-demographic change. In addition, infrastructural and technical restrictions (no computer or mobile devices, difficulties with the internet connection), lack of technical knowledge, or not 
being acquainted with various ways of communication caused further complications. Finally, the target municipalities exhibited significant concern regarding face-to-face interactions. However, transdisciplinary research includes and often actually demands personal interactions and communication, which has been impossible during the current pandemic. Similarly, it has been impossible to organize face-to-face workshops or significant public lectures and debates. Therefore, the interaction focussed on exchanges via classic communication tools, such as fact sheets, contributions in local newspapers, or telephone conversations with policy makers and citizens. Stepping up the effort in this regard should fill at least some of the gaps opened up due to the present unique situation, but it can never fully replace what had been planned in terms of transdisciplinary collaboration.

\section{Conclusion - some self-reflections}

Interactions, in a transdisciplinary sense, have been severely limited because of the impossibilities outlined above. This has delayed the research and hampered some activities such as organizing workshops, while public lectures have been postponed until after the project deadline. However, our results show the benefits of an early integration of the stakeholders in the process; they also support the assumption that controversial, conflicting stories with negative connotations may be a serious barrier for comprehensive transdisciplinary research. We argue that transdisciplinary research has great potential for improving natural hazard management, not only in the production of knowledge but also in the development of solutions to real-world problems. There nevertheless remain substantial limitations and concerns which must be considered right from the outset of any research project dealing with flood risk management in a politically sensitive policy area like demographic change. Our research questions (on the impact of demographic change on flood risk management policy) and experiences of transdisciplinary research (the restrictions on it and the concrete recommendations which we made for the transdisciplinary research concerned) within this unhappy story could be applied to research on BRs (notably the tension between sustainable management of UNESCO biosphere reserves and the protection of municipalities) mentioned at the beginning of this article. Accordingly, we argue that our findings can be transferred to BR management and other policy areas. The UNESCO MAB Programme and its World Network of Biosphere Reserves foresees strong interactions with, and inclusion of, inhabitants, visitors and researchers in BR activities, from research to negotiations concerning land use management (see for example Austrian MABNationalkomitee 2016, 2017, 2019, or UNESCO MAB 2017). Here, our insights could be helpful. We are convinced that our main conclusion - that research activities which are embedded within, and closely connected to, their specific regional and local socio-political contexts have a much greater chance of becoming a success story and reaching acceptance among the different stakeholders - could be applied to other complex situations in which both contentious and very different issues are addressed at the same time.

\section{Acknowledgements}

The research project Demographic Change and Hydrological Hazards: Flood Risk Management in Alpine Areas Facing Population Decline and Demographic Ageing (DemoHazAlps) that led to this paper was funded by the Austrian Academy of Sciences (ÖAW) within the research programme Earth System Sciences (ESS). Open access funding provided by BOKU Vienna Open Access Publishing Fund

\section{References}

Ammering, U., B. Macher, M. Mannheim, Y. Lesewa, A. Kratzer, T. Töpfer \& N. Weixlbaumer2020. Experimental networks for sustainability. Urban biosphere reserves as engines of transformation. Projektendbericht. Wien: Akademie der Wissenschaften.

Angelstam, P., K. Andersson, M. Annerstedt, R. Axelsson, M. Elbakidze, P. Garrido, K.P. Grahn, I. Jönsson, S. Pedersen, P. Schlyter, E. Skärbäck, M. Smith \& I. Stjernquist 2013. Solving problems in social-ecological systems: Definition, practice and barriers of transdisciplinary research. Ambio 42: 254-265. doi: 10.1007/s13280-012-0372-4

Apple, M.E. 2021. On the impact of the COVID-19 pandemic on alpine research projects in Montana. eco. mont - Journal on protected mountain areas research and management 13(1): 67-70. doi: 10.1553/eco.mont-13-1s67

Austrian MAB-Nationalkomitee 2016. Kriterien für Biosphärenparks in Österreich. Available at: http:// www.biosphaerenparks.at/index.php/de/nationalekriterien (accessed: 18/02/2021)

Austrian MAB-Nationalkomitee 2017: Positionspapier zur Nutzung von erneuerbaren Energien in österreichischen Biosphärenparks. Available at: http:// www.biosphaerenparks.at/index.php/de/nationalekriterien (accessed: 18/02/2021)

Austrian MAB-Nationalkomitee 2019. Leitfaden zur Umsetzung des Lima-Aktionsplans 2016-2025 in österreichischen Biosphärenparks. http://www.biosphaerenparks.at/index.php/de/nationale-kriterien (accessed: 18/02/2021)

Clar, C. 2019. How demographic developments determine the management of hydrometeorological hazard risks in rural communities: The linkages between demographic and natural hazards research. WIREs Water 6(6): e1378. doi: 10.1002/wat2.1378

Clar, C. (forthcoming). Bringing the political back in: Call for a critical interdisciplinary perspective on urban sustainable development. In: Kogler, R. \& A. Hamedinger (eds.), Interdisziplinäre Stadtforschung. Themen und 
Perspektiven. Bielefeld: Reihe Urban Studies, Transcript. Clar, C., L. Löschner, R. Nordbeck, T. Fischer \& T. Thaler 2021. Population dynamics and natural hazard risk management: conceptual and practical linkages for the case of Austrian policy making. Natural Hazards 105: 1765-1796. doi: 10.1007/s11069-020-04376-Z

Daniels, S.E. \& G.B. Walker 2001. Working through environmental conflict. The collaborative learning approach. Westport, CT.

Hoffmann, S., C. Pohl \& J.G. Hering 2017. Methods and procedures of transdisciplinary knowledge integration: empirical insights from four thematic synthesis processes. Ecology and Society 22(1): 27. doi: 10.5751/es-08955-220127

Jahn, T., M. Bergmann \& F. Keil 2012. Transdisciplinarity. Ecological Economics 79: 1-10. doi: 10.1016/j. ecolecon.2012.04.017

Klein, J.T., R. Häberli, R.W. Scholz, W. Grossenbacher-Mansuy, A. Bill \& M. Welti 2001. Transdisciplinarity: joint problem solving among science, technology, and society. An effective way for managing complexity. Basel.

Kratzer, A. 2018a. Biosphere reserves as model regions for sustainability transitions? Insights into the peripheral mountain area Grosses Walsertal (Austria). Applied Geography 90: 321-330. doi: 10.1016/j.apgeog.2017.04.003

Kratzer, A. 2018b. Biosphere reserves research: a bibliometric analysis. eco.mont - Journal on protected mountain areas research and management 10(2): 36-49. doi: 10.1553/eco.mont-10-2s36

Krueger, T., C. Maynard, G. Carr, A. Bruns, E.N. Mueller \& S. Lane 2016. A transdisciplinary account of water research. WIREs Water 3(3): 369-389. doi: $10.1002 /$ wat2.1132

Löschner, L., R. Nordbeck, P. Scherhaufer \& W. Seher 2016. Scientist-stakeholder workshops: A collaborative approach for integrating science and decision-making in Austrian flood-prone municipalities. Environmental Science \& Policy 55(2): 345-352. doi: 10.1016/j.envsci.2015.08.003

Meessen, H., J. Svajda,T. Kohler, V. Fabriciusová, D. Galvánek, M. Bural, M. Káčerová \& J. Kadlečík 2015. Protected areas in the Slovak Carpathians as a contested resource between metropolitan and mountain stakeholders. Journal of alpine research - Revue de géographie alpine 103-3. doi: 10.4000/rga.3055.

Michel, A.H. 2019. How conceptions of equity and justice shape national park negotiations: The case of Parc Adula, Switzerland. eco.mont - Journal on protected mountain areas research and management 11(1): 25-31. doi: 10.1553/eco.mont-11-1s25.

Pielke, R.A. 2010. Expert advice and the vast sea of knowledge. In: Bogner, A., K. Kastenhofer \& H. Torgersen, Inter- und Transdisøiplinarität im Wandel? Neue Perspektiven auf problem-orientierte Forschung und Politikberatung. Baden-Baden: 169-187.

Rumpolt, P.A., A. Kratzer, M. Coy \& N. Weixlbaumer 2016. Regional economic and perceptional analysis in an UNESCO biosphere reserve. Future strategies for re- gional development in the BR Großes Walsertal against the background of demographic change: What comes next? Projektendbericht. Wien: Österreichische Akademie der Wissenschaften.

Scherhaufer, P. \& H. Grüneis 2014. Herausforderungen und Grenzen partizipativer Projektarbeit Zwei Beispiele aus der transdisziplinären Klimawandelanpassungsforschung und erste Lösungsansätze. Umweltpsychologie 18: 189-210.

Scholz, R.W. \& G. Steiner 2015. The real type and ideal type of transdisciplinary processes: part II what constraints and obstacles do we meet in practice? Sustainability Science 10: 653-671. doi: 10.1007/s11625015-0327-3

Seebauer, S., S. Ortner, P. Babcicky \& T. Thaler 2019. Bottom-up citizen initiatives as emergent actors in flood risk management: Mapping roles, relations and limitations. Journal of Flood Risk Management 12: e12468.

Stauffacher, M., T. Flüeler, P. Krütli \& R.W. Scholz 2008. Analytic and dynamic approach to collaboration: A transdisciplinary case study on sustainable landscape development in a swiss prealpine region. Systemic Practice and Action Research 21(6): 409-422. doi: 10.1007/s11213-008-9107-7

Thompson, M.A., S. Owen, J.M. Lindsay, G.S. Leonard \& S.J. Cronin 2017. Scientist and stakeholder perspectives of transdisciplinary research: Early attitudes, expectations, and tensions. Environmental Science \& Policy 74: 30-39. doi: 10.1016/j.envsci.2017.04.006

UNESCO MAB 2017. MAB Strategy (2015-2025) Lima Action Plan (2016-2025) Lima Declaration Network. of Biosphere Reserves (2016-2025). A new roadmap for the Man and the Biosphere (MAB) programme and its world network of biosphere reserves. Paris: UNESCO.

Vilsmaier, U. 2010. Transdisciplinarity and protected areas: A matter of research horizon. eco.mont Journal on protected mountain areas research and management 2(2): 37-43. doi: 10.1553/eco.mont-2-2s37

von Lindern, E., R. Knoth \& X. Junge 2019. Akzeptanz, Identifikation und Engagement: Ansichten und Mitwirkung der Bevölkerung in UNESCO Biosphärenreservaten (AkIdEn). Bern \& Wien: Forum Landschaft, Alpen, Pärke - Akademie der Naturwissenschaften Schweiz (SCNAT) \& Österreichisches Nationalkomitee für das UNESCO-Programm "Man and the Biosphere".

Warner, B. \& C. Damm 2019. Relocation of dikes: Governance challenges in the biosphere reserve "River Landscape Elbe-Brandenburg". In: Hartmann, T., L. Slavíková \& S. McCarthy (eds.), Nature-based flood risk management on private land. Cham: 171-180.

\section{Authors}

\section{Thomas Thaler ${ }^{1}$}

holds a PhD in Environmental Science and is currently working as a post-doc researcher at the Institute 
of Mountain Risk Engineering at the University of Natural Resources and Life Sciences.

\section{Christoph Clar ${ }^{1,2}$}

holds a PhD in Political Science and is currently working as a post-doc researcher at both the Institute of Forest, Environmental and Natural Resources Policy and the Institute of Mountain Risk Engineering at the University of Natural Resources and Life Sciences.

\section{Lena Junger ${ }^{3}$}

holds a Master's degree in Spatial Planning and is currently working as a $\mathrm{PhD}$ researcher at the Institute of Spatial Planning, Environmental Planning and Land Rearrangement at the University of Natural Resources and Life Sciences.

\section{Ralf Nordbeck ${ }^{2}$}

holds a $\mathrm{PhD}$ in Political Science and is currently a Senior Scientist at the Institute of Forest, Environmental and Natural Resources Policy at the University of Natural Resources and Life Sciences.

${ }^{1}$ Institute for Mountain Risk Engineering, University of Natural Resources and Life Sciences, Vienna

${ }^{2}$ Institute of Forest, Environmental and Natural Resource Policy, University of Natural Resources and Life Sciences, Vienna

${ }^{3}$ Institute of Spatial Planning, Environmental Planning and Land Rearrangement, University of Natural Resources and Life Sciences, Vienna 